\title{
Competence Level in the Use of Social Media by Urban Poultry Farmers in Ikorodu LGA, Lagos State, Nigeria
}

\author{
C. O. Michael,* F. E. Esene, S. E. Okundaye \\ Department of Agricultural Economics and Extension Services, University of Benin, Benin City, Nigeria
}

\begin{abstract}
This study examined the level of competence in the use of social media by urban poultry farmers in Ikorodu LGA, Lagos State, Nigeria. Purposive sampling technique was used to select communities in Ikorodu LGA that had high predominance of poultry farmers. A structured questionnaire was used for data collection, with a target audience of 120 poultry farmers. Objectives were analyzed using simple descriptive statistics such as such as frequency counts, percentages, mean statistics and standard deviation while the hypotheses were tested using the logit and multiple regressions. Results showed; Facebook $(\bar{x}=3.75)$, WhatsApp $(\bar{x}=2.57)$ and Google $(\bar{x}=2.35)$ as preferred social media. Majority had high competence in the use of Facebook $(\bar{x}=3.75)$, WhatsApp $(\bar{x}=3.44)$ and Google $(\bar{x}=3.25)$ but had low level of competence in Pinterest $(\bar{x}=0.58)$, Slideshare $(\bar{x}=0.82)$ and Academia $(\bar{x}=0.85)$. Major information sourced from social media were daily routine management and general housing information. Farm status $(\bar{x}=-2.57)$, farm experience $(\bar{x}=2.50)$ and stock size $(\bar{x}=2.71)$ were significant at $1 \%$ with level of competence using social media. preferred sources of social media were Facebook, Whatsapp and Google which will help in effective information dissemination to the poultry farmers in the study area.
\end{abstract}

Keywords: Competence, Poultry Farmers, Social media, Urban

DOI: $10.7176 / \mathrm{NMMC} / 81-03$

Publication date:June $30^{\text {th }} 2019$

\section{INTRODUCTION}

Farmers and agricultural communicators often lag in the adoption of technology and have historically been limited in their access to new communication technologies (Morrison, 2015; Tweeten, 2014). Over the past decade, social networking sites have become a mainstream cultural phenomenon (Boyd and Ellison, 2008) and Agricultural researchers have caught a glimpse of the tremendous role social media can play in establishing connections, facilitating dissemination of Agricultural research findings and in the exchange of information (Collence, 2012; Olaniyi, 2013).

Henderson and Bowley (2010) defined social media as "collaborative online applications and technologies that enable participation, connectivity, user-generated content, sharing of information, and collaboration amongst a community of users." Social media depends on mobile and web based technologies to create highly interactive platforms through which individuals share, co-create, discuss and modify user generated content (Kietzmann and Christopher, 2011). There are various SMs that enable individuals to communicate to one another online and they include; Facebook, twitter, YouTube, Instagram, WhatsApp, blog, LinkedIn etc. Facebook is the most popular social networking site used among agricultural organizations because it is well known among the target audience and has received the most scholarly attention (Tweeten, 2014).

According to Abiola and Edeoghon (2014) urban poultry production can be defined as the rearing of domesticated birds such as chicken, turkey, guinea fowl, pigeon and other game birds in urban areas. Poultry can either be reared in large scale (commercial scale), medium scale or small scale (backyard poultry). Large scale poultry farms having a range of 10000 and above and medium scale poultry farms having 2000-10000 birds are mostly found in urban areas where there is access to adequate production facilities and marketing outlet while small scale poultry farms are between 50-2000 birds (Busari and Okanlanwso 2015; Aning 2006). Poultry farming is an important employer of labour and a source of capital for the farm household. Apart from these, poultry is a major source of high quality protein, usually in the form of meat and eggs to the populace. Poultry products such as eggs are equally important in improving nutritional health status particularly for vulnerable groups like children and pregnant women (Oladeji, 2011).

In recent years, efforts have been made to educate farmers and individuals in the Agricultural sector about social media and its importance. Social media is of great value to urban poultry farmers as it is used to access latest issues or current trends about poultry farming such as skills for daily inspection and sanitary of the farm, vaccination, debeaking, proper feeding management of resources like feeds, keeping record of farm activities and so on; which is expected to enhance the quality of their production output. The development and use of social media is also playing a critical role as regards availability of markets and market information, which gives farmers the potential to bargain and improve their incomes, to seize market opportunities through the adjustment of production plans and better allocation of production factors, and also to use the information to make choices about marketing (Kwadwo\& Daniel, 2012).

The general objective of this study is to assess the level of competence in the use of social media by urban 
poultry farmers while the specific objectives are;

1. examine farm characteristics of urban poultry farmers in the study area;

2. assess the level of competence of urban poultry farmers in the use of social media in the study area;

3. ascertain the preferred sources of social media for farm information by urban poultry farmers in the study area;

4. assess the farm information used by urban poultry farmers from social media in the study area;

\section{Hypotheses:}

1. There is no significant relationship between the poultry farmers preferred sources of social media and their level of competence.

2. There is no significant relationship between the farm characteristics of the poultry farmers and their level of competence in the use of social media.

\section{METHODOLOGY}

The research work was conducted in Ikorodu, Lagos State, Nigeria. Ikorodu LGA was chosen as the study area being the overall second largest LGA in the State (LSBD, 2012). The LGA, with a land mass of about 161.95 $\mathrm{km}^{2}$, covering 22 kilometers on longitude $20^{\circ} 53^{\prime} \mathrm{E}$ and $29^{\circ} 14^{\prime} \mathrm{E}$ as well as latitude $60^{\circ} 24^{\prime} \mathrm{N}$ and $60^{\circ} 1^{\prime} \mathrm{N}$ (LSBD, 2012). Four communities were purposively selected in the study area namely, Odogunyan, Lasunwon, Eyita and Parafa because of the predominance of poultry farmers in these areas. Thirty five poultry farmers were randomly selected using the simple random method to yield a total of 120 respondents for the study. Data were collected with the aid of well-structured questionnaire. Data were analyzed using simple descriptive statistics such as frequency counts, percentages, mean statistics and standard deviation to capture the objectives. Logit and multiple regressions were used to test hypotheses.

\section{RESULTS AND DISCUSSION}

\subsection{Farm Characteristics of Respondents}

The results on Table 1 shows that majority (79.2\%) of the respondents are into poultry production full time. This implies that poultry farmers in the study area rely on poultry farming as their major source of income. The mean farming experience was 13 years, implying that the poultry farmers in the study area have much experience on poultry production. Also majority (41.7\%) reared between 2000-10,000 birds, while 4134 birds was average stock size. This implies that most of the respondents rear poultry on a medium scale. $78.3 \%$ of the farmers adopted the method of rearing birds in battery cages which implies that most of the farmers have the knowledge of improved methods of rearing birds which might have been sourced from one of the ICTs possibly on social media, $44.2 \%$ of the respondents rear both broilers and layers while majority (49.2\%) obtain their farm inputs from the local market. 
Table 1: Farm characteristics of respondents

\begin{tabular}{|c|c|c|c|c|}
\hline Variable & Frequency & Percentage & Mean & Std. Dev \\
\hline \multicolumn{5}{|l|}{ Farm status } \\
\hline NR & 7 & 5.8 & & \\
\hline Full time & 95 & 79.2 & & \\
\hline Part-Time & 18 & 15 & & \\
\hline \multicolumn{5}{|c|}{ Farming Experience (Years) } \\
\hline NR & 3 & 2.5 & & \\
\hline $0-10$ years & 52 & 43.3 & & \\
\hline $11-20$ years & 38 & 31.7 & & \\
\hline $21-30$ years & 23 & 19.2 & 13.15 & 7.1 \\
\hline $31-40$ years & 4 & 3.3 & & \\
\hline \multicolumn{5}{|l|}{ Stock size } \\
\hline NR & 6 & 5 & & \\
\hline $0-2000$ & 40 & 33.3 & & \\
\hline $2001-4000$ & 21 & 17.5 & & \\
\hline $4001-6000$ & 20 & 16.7 & $4,133.7$ & 100.7 \\
\hline $6001-8000$ & 1 & 0.8 & & \\
\hline $8001-10000$ & 8 & 6.7 & & \\
\hline 10000 and above & 24 & 20 & & \\
\hline \multicolumn{5}{|l|}{ Production system } \\
\hline NR & 6 & 5 & & \\
\hline Cages & 94 & 78.3 & & \\
\hline Yarding & 12 & 10 & & \\
\hline Free Rangers & 8 & 6.7 & & \\
\hline \multicolumn{5}{|l|}{ Type of poultry } \\
\hline NR & 11 & 9.2 & & \\
\hline Broiler & 5 & 4.2 & & \\
\hline Layers & 51 & 42.5 & & \\
\hline Both & 53 & 44.2 & & \\
\hline \multicolumn{5}{|c|}{ Source of poultry inputs } \\
\hline NR & 9 & 7.5 & & \\
\hline Local market & 59 & 49.2 & & \\
\hline Other Farms & 29 & 24.2 & & \\
\hline Ext. Agents Outlet & 8 & 6.6 & & \\
\hline Vet. Doc Outlet & 15 & 12.5 & & \\
\hline
\end{tabular}

Source: Field survey data, 2017.

$\mathrm{NR}=$ No Response

\subsection{Respondents' Level of Competence in the Use of Social Media}

Table 2 shows that the mean score for the respondents' level of competence in all the forms of social media was 28.40. This implies that respondents with a mean $<28.40$ had low competence in the use of social media while respondents with a mean $>28.41$ had high competence in the use of social media. The results also show that majority $(53.3 \%)$ of the respondents had high competence in the use of social media generally. This implies that most urban poultry farmers in the study area can adequately utilize social media.

Table 2: Respondents level of competence in the use of social media

\begin{tabular}{llll}
\hline & & Frequency & Percent \\
\hline Valid & (Low Competence $<28.40)$ & 56 & 46.7 \\
& (High Competence $>28.41)$ & 64 & 53.3 \\
& Total & 120 & 100.0 \\
\hline
\end{tabular}

Source: Field survey data, 2017

$\operatorname{Min}=1$

$\operatorname{Max}=54$,

Mean $=28.4$

Std. Dev $=13.9$

Table 3 shows that the respondents are highly competent in the use of Facebook $(\bar{x}=3.75)$, WhatsApp $(\bar{x}=$ 3.44), Google $(\bar{x}=3.25)$, BBM $(\bar{x}=2.68)$ and YouTube $(\bar{x}=2.65)$. This implies that respondents can use the functions of these SMs independently with almost no assistance for their needs. The results also shows that respondents have very low competence in the use of Pinterest $(\bar{x}=0.58)$, Slideshare $(\bar{x}=0.82)$ and Academia $(\bar{x}=$ 
0.85). This implies that most respondents have little or no knowledge about these forms of social media therefore they do not use them.

The standard deviation value $(\mathrm{SD}=0.72)$ for Facebook, for WhatsApp $(\mathrm{SD}=1.22)$, for Google $(\mathrm{SD}=1.36)$, for BBM ( $\mathrm{SD}=1.70)$, YouTube $(\mathrm{SD}=1.66)$, all have a dispersion of $3.75 \pm 0.72,3.25 \pm 1.22,2.68 \pm 1.36,2.65$ \pm 1.66 respectively; which affirms that they all deviate negatively from the mean showing that the significance is not strong across all the population. In Facebook however, $(3.75 \pm 0.72)$, there is no negative deviation from the mean. This implies high competence of Facebook among all respondents.

Table 3: Distribution of respondents' level of competence in the use of the forms of social media

\begin{tabular}{lll}
\hline & & Competence \\
Variable & Mean & Std. Dev \\
\hline Facebook & $3.75^{*}$ & 0.72 \\
Instagram & 2.49 & 1.71 \\
Twitter & 2.47 & 1.72 \\
YouTube & $2.65^{*}$ & 1.66 \\
Skype & 1.54 & 1.56 \\
WhatsApp & $3.44^{*}$ & 1.22 \\
LinkedIn & 1.24 & 1.50 \\
Pinterest & 0.57 & 0.91 \\
BBM & 2.68 & 1.70 \\
Slideshare & 0.82 & 1.17 \\
Blogger & 1.11 & 1.47 \\
Snapchat & 1.52 & 1.58 \\
Google & $3.25^{*}$ & 1.36 \\
Academia & 0.85 & 1.27 \\
\hline
\end{tabular}

Source: Field survey data, 2017.

$*$ Mean $\geq 2.5=$ High competence

\subsection{Preferred Sources of Social Media for Farm Information by Respondents}

Table 4 shows that the most preferred sources of social media for farm information by the respondents were WhatsApp $(\bar{x}=2.57)$, Facebook $(\bar{x}=2.39)$ and Google $(\bar{x}=2.35)$ respectively. This result corroborates with Stanley (2013) who said that most farmers have adopted the use of SMs like Facebook and WhatsApp which have made interaction between farmers less complicated, easy and hassle free. The results also reveal that $(\mathrm{SD}=0.96)$ for Facebook, for WhatsApp ( $\mathrm{SD}=0.97)$ and for Google $(\mathrm{SD}=1.16)$, all have a dispersion of $2.57 \pm 0.97,2.39 \pm$ $0.96,2.39 \pm 1.16$; which shows that they all deviate negatively from the mean showing that the significance is not very strong across all the respondents.This means that some respondents have other preferred sources of social media. The least preferred sources of social media were Pinterest $(\bar{x}=0.42)$ Slideshare $(\bar{x}=0.46)$ and Skype $(\bar{x}=.47)$.

Table 4: Preferred sources of social media for farm information by respondents

\begin{tabular}{lll}
\hline Variable & \multicolumn{2}{c}{ Preference as information sources } \\
Social media & Mean & 0.96 \\
Facebook & $2.39^{*}$ & 1.08 \\
Instagram & 0.84 & 1.25 \\
Twitter & 1.32 & 1.35 \\
YouTube & 1.69 & 0.82 \\
Skype & 0.47 & 0.97 \\
WhatsApp & $2.57^{*}$ & 0.84 \\
LinkedIn & 0.48 & 0.60 \\
Pinterest & 0.28 & 1.33 \\
BMM & 1.48 & 0.82 \\
Slideshare & 0.46 & 0.90 \\
Blogger & 0.53 & 0.82 \\
Snapchat & 0.48 & 1.16 \\
Google & $2.35^{*}$ & 0.95 \\
Academia & 0.55 & \\
\hline
\end{tabular}

Source: Field survey data, 2017.

*Most preferred $\geq \mathbf{2 . 0}$

Farm Information Used by Respondents from Social Media

Table 5 revealed that for information on day old stock, majority of the respondents utilized WhatsApp $(50.8 \%)$, Google (49.2\%) and Facebook (46.7\%); for information on market prices, majority of the respondents 
also utilized WhatsApp (78.3\%), Google (60.0\%) and Facebook (55.8\%); for information on pests and diseases control majority of the respondents utilized WhatsApp $(74.2 \%)$ and Google $(61.7 \%)$; for information on feeding/feed formulation majority of the respondents utilized Google (60.0\%) Facebook (49.2\%) and WhatsApp (42.5\%); for information on breeding techniques, majority of the respondents utilized WhatsApp (69.2\%), Google $(55.0 \%)$ and Facebook (50.8\%) and very few utilized YouTube $(6.7 \%)$; for information on government policies majority of the respondents utilized Facebook (59.2\%), Google (59.2\%), WhatsApp (55.8\%) and Twitter (34.2\%), for information on daily routine management, most of the respondents utilized Facebook $(82.5 \%)$, WhatsApp (75.8\%), Google (75\%) and BBM (44.2\%); for information on debeaking, detoeing and deworming, majority of the respondents utilized Facebook (51.7\%) and YouTube (35.8\%); for information on general housing information, majority of the respondents utilized Google (82.5\%) Facebook (55.8\%) and WhatsApp (52.5\%). This implies that the forms of SMs mostly sourced for farm information are, WhatsApp (59.8\%), Google (57.6\%) and Facebook (55\%)respectively, showing a significant relationship between the preferred sources of SMs by the respondents and their farm information. This is in line with the results in Table 4which revealed that the preferred sources of the respondents are Facebook, WhatsApp and Google. This also indicates that Facebook, WhatsApp and Google are SMs that are very useful to poultry farmers for farm information. The results in Table 5 also reveals that the farm information mostly sourced from SMs by the respondents are daily routine management, general housing information, market prices and pests and diseases control respectively.

Table 5: Farm information used by respondents from social media

\begin{tabular}{|c|c|c|c|c|c|c|c|c|c|c|}
\hline $\begin{array}{l}\text { Social } \\
\text { Media }\end{array}$ & Variable & & & & & & & & & $\begin{array}{l}\text { Gross Percentage } \\
\text { per SMs }\end{array}$ \\
\hline & $\begin{array}{l}\text { Day old } \\
\text { stocks }\end{array}$ & $\begin{array}{l}\text { Market } \\
\text { prices }\end{array}$ & $\begin{array}{l}\text { Pest/disease } \\
\text { control }\end{array}$ & $\begin{array}{l}\text { Feeding/feed } \\
\text { formulation }\end{array}$ & $\begin{array}{l}\text { Breeding } \\
\text { techniques }\end{array}$ & $\begin{array}{l}\text { Government } \\
\text { policies }\end{array}$ & $\begin{array}{l}\text { Daily routine } \\
\text { management }\end{array}$ & $\begin{array}{l}\text { Debeaking, } \\
\text { detoeing\& } \\
\text { deworming }\end{array}$ & $\begin{array}{l}\text { General housing } \\
\text { information }\end{array}$ & \\
\hline
\end{tabular}

\begin{tabular}{|c|c|c|c|c|c|c|c|c|c|c|}
\hline Facebook & $56(46.7)$ & $67(55.8)$ & $52(43.3)$ & $59(49.2)$ & $61(50.8)$ & $71(59.2)$ & 99 (82.5) & $62(51.7)$ & $67(55.8)$ & $55.00 \%$ \\
\hline Instagram & $23(19.2)$ & $38(31.7)$ & $30(25.0)$ & $17(14.2)$ & 29 (24.2) & $13(10.8)$ & $21(17.5)$ & $11(9.2)$ & $32(26.7)$ & $18.17 \%$ \\
\hline Twitter & $31(25.8)$ & $40(33.3)$ & $21(17.5)$ & $29(24.2)$ & $39(32.5)$ & $41(34.2)$ & $17(14.2)$ & $13(10.8)$ & $37(30.8)$ & $24.81 \%$ \\
\hline YouTube & $8(6.6)$ & $30(0.25)$ & $25(0.21)$ & $44(36.7)$ & $8(6.7)$ & $19(15.8)$ & $32(26.7)$ & $43(35.8)$ & $19(15.8)$ & $16.06 \%$ \\
\hline Skype & $19(15.8)$ & $32(26.7)$ & $51(42.5)$ & $21(17.5)$ & $27(22.5)$ & $19(15.8)$ & $32(26.7)$ & $19(15.8)$ & $38(31.7)$ & $23.89 \%$ \\
\hline WhatsApp & $61(50.8)$ & $94(78.3)$ & $89(74.2)$ & $51(42.5)$ & $83(69.2)$ & $67(55.8)$ & $91(75.8)$ & $39(32.5)$ & $63(52.5)$ & $59.80 \%$ \\
\hline LinkedIn & $20(16.7)$ & $19(15.8)$ & $43(35.8)$ & $31(25.8)$ & 34 (28.3) & $12(10.0)$ & $13(10.8)$ & $29(24.2)$ & $39(32.5)$ & $22.21 \%$ \\
\hline Pinterest & $22(18.3)$ & $42(35.0)$ & $23(19.2)$ & $33(27.5)$ & $15(12.5)$ & $9(7.5)$ & 34 (28.3) & $34(28.3)$ & $12(10.0)$ & $20.73 \%$ \\
\hline BMM & $31(25.8)$ & $8(6.7)$ & $28(23.3)$ & $35(29.2)$ & $28(23.3)$ & $18(15.0)$ & 53 (44.2) & $12(10.0)$ & $44(36.7)$ & $23.80 \%$ \\
\hline Slideshare & $21(17.5)$ & $12(10.0)$ & $34(28.3)$ & $12(10.0)$ & $26(21.7)$ & $34(28.3)$ & $24(20.0)$ & $19(15.8)$ & $16(13.3)$ & $18.32 \%$ \\
\hline Blogger & $17(14.2)$ & $29(24.2)$ & $11(9.2)$ & $30(25.0)$ & 14 (11.7) & $26(21.7)$ & $22(18.3)$ & $7(5.8)$ & $28(23.3)$ & $17.04 \%$ \\
\hline Snapchat & $39(32.5)$ & $19(15.8)$ & $20(16.7)$ & $38(31.7)$ & $27(22.5)$ & $33(27.5)$ & $19(15.8)$ & $27(22.5)$ & $12(10.0)$ & $45.83 \%$ \\
\hline Google & $59(49.2)$ & $72(60.0)$ & $74(61.7)$ & $72(60.0)$ & $66(55.0)$ & $71(59.2)$ & $90(75.0)$ & $19(15.8)$ & 99 (82.5) & $\mathbf{5 7 . 6 0 \%}$ \\
\hline Academia & $23(19.2)$ & $19(15.8)$ & $9(7.5)$ & $32(26.7)$ & $31(25.8)$ & $20(16.7)$ & $35(29.2)$ & $12(10.0)$ & $19(15.8)$ & $15.67 \%$ \\
\hline
\end{tabular}

Source: Field survey data, 2017.

Figures in parentheses represent percentages

\subsection{Hypotheses 1: Respondents' Preferred Sources of Social Media and their Level of Competence.}

It was observed in Table 6 that Facebook $(t=4.57 ; \mathrm{p} \leq 0.01)$, Google $(\mathrm{t}=3.61 ; \mathrm{p} \leq 0.01)$; WhatsApp $(\mathrm{t}=3.35 ; \mathrm{p} \leq 0.01)$ YouTube $(\mathrm{t}=2.73 ; \mathrm{p} \leq 0.01)$, were the significant variables that influenced respondents' competence in the use of social media. This implies that most of the respondents can adequately use their preferred sources of SMs therefore,there is a significant relationship between the respondents preferred sources of social media and their level of competence. Results also show that Pinterest $(\mathrm{t}=-2.19 ; \mathrm{p}=0.03)$ had a negative but significant relationship with the respondents competence in the use of social media, which implies that Pinterest is one of the most not preferred sources and therefore the respondents have very low competence. Results on Table 6 also show that Twitter $(\mathrm{t}=-0.904 ; \mathrm{p}=0.37)$, Instagram $(\mathrm{t}=-0.59 ; \mathrm{p}=0.56)$ and Blogger $(\mathrm{t}=-0.01 ; \mathrm{p}=0.99)$ are negative and not significant to the level of competence of the respondents showing that urban poultry farmers had very low competence in them. The results also show the $\mathrm{R}$ square value $(0.78)$ which indicates that about $78 \%$ of variation in the preferred sources of social media could be attributed to the significant social media indicated above. 
Table 6: Relationship between respondents' preferred sources of social media and their level of competence.

\begin{tabular}{|c|c|c|c|c|c|}
\hline & \multicolumn{2}{|c|}{ Unstandardized Coefficients } & \multicolumn{2}{|c|}{ Standardized Coefficients } & \\
\hline Regressors & B & Std. Error & Beta & $\mathbf{T}$ & Sig \\
\hline (Constant) & 5.46 & 2.34 & & $2.33 * *$ & 0.02 \\
\hline Facebook & 3.65 & 0.80 & 0.33 & $4.57 * *$ & 0.00 \\
\hline Instagram & -0.51 & 0.87 & -0.04 & -0.59 & 0.56 \\
\hline Twitter & -0.68 & 0.76 & -0.05 & 0.904 & 0.37 \\
\hline YouTube & 1.89 & 0.69 & 0.18 & $2.73 * *$ & 0.01 \\
\hline Skype & 0.15 & 1.58 & 0.01 & 0.10 & 0.92 \\
\hline WhatsApp & 2.66 & 0.80 & 0.18 & $3.35 * *$ & 0.00 \\
\hline LinkedIn & 2.65 & 1.46 & 0.16 & 1.82 & 0.07 \\
\hline Pinterest & -4.04 & 1.85 & -0.17 & $-2.19 *$ & 0.03 \\
\hline BMM & 0.87 & 0.69 & 0.08 & 1.26 & 0.21 \\
\hline Slideshare & 2.01 & 1.43 & 0.12 & 1.41 & 0.16 \\
\hline Blogger & -0.02 & 1.61 & 0.00 & -0.01 & 0.99 \\
\hline Snapchat & 1.93 & 1.06 & 0.11 & 1.82 & 0.07 \\
\hline Google & 2.52 & 0.70 & 0.21 & $3.61 * *$ & 0.00 \\
\hline Academia & 1.67 & 1.24 & 0.11 & 1.35 & 0.18 \\
\hline
\end{tabular}

Source: Field survey data, 2017.

$\mathrm{R}^{2}=0.781$

*Significant at $5 \%$

**Significant at $1 \%$

Hypotheses 2: Relationship between the Farm Characteristics of the Poultry Farmers and their Level of Competence in the Use of Social Media.

The results in Table 7 was tested using the logit regression and show that farm status $(\bar{x}=-2.57)$ is negatively significant to the level of competence of the use of social media by the respondents at $1 \%$. This implies that most part time poultry farmers have a higher level of competence in the use of social media compared to the full time farmers. This could be attributed to the fact that most part time farmers need to get accurate information on the particular business they are venturing into since they are involved in other businesses. It is observed in Table 7 that farm experience $(\bar{x}=2.50)$ and stock size $(\bar{x}=2.71)$ are positively significant to the level of competence of the respondents in the use of social media at $1 \%$. This implies that respondents with more years of farming experience have higher level of competence in the use of social media compared to respondents with few years of farming experience. This may be attributed to the fact that poultry farmers with more experience tend to seek more information due to their exposure and experience compared to poultry farmers with less experience. It also implies that respondents with larger stock size have higher level of competence in the use of social media compared to those with smaller stock size. The results also show the $\mathrm{R}$ square value $(0.2836)$ which indicates that only about $28.36 \%$ of variation in the respondents' level of competence in the use of SMs could be attributed to the significant farm characteristics indicated below.

Table 7: Relationship between the farm characteristics of the poultry farmers and their level of competence in the use of social media.

\begin{tabular}{lllll}
\hline Variable & Coeff. & Std. Error & $\mathrm{Z}$ & $\mathrm{P}>|\mathrm{z}|$ \\
\hline Farm Status & -1.340 & .5222 & $-2.57^{* *}$ & 0.01 \\
Farm Experience & 2.345 & .9372 & $2.50^{* *}$ & 0.01 \\
Stock Size & 0.2701 & 0.0994 & $2.71^{* *}$ & 0.01 \\
Production System & 0.2740 & 0.3794 & 0.72 & 0.47 \\
Type of Poultry & 0.2094 & 0.2349 & 0.89 & 0.37 \\
Source of Poultry Inputs & 0.1333 & 0.1989 & 0.67 & 0.50 \\
Constant & 0.7048 & 0.8749 & 0.81 & 0.42 \\
\hline
\end{tabular}

Source: Field survey data, 2017

* Significant at 5\%

** Significant at $1 \%$

Number of observation $=118$

$\mathrm{R}^{2}=0.2836$

\section{CONCLUSION}

This study concludes that the respondents preferred those SMs that could show videos, pictorial explanations and writings such as Facebook, WhatsApp and Google. This implies that what we see, hear and read at the same time can help in competence and memory retention.

Urban poultry farmers should learn to use of some important or current SMs such as Pinterest, Slideshare, 
Blogger and Academia.

\section{REFERENCES}

Abiola, M. O., \& Edeoghon, C. O (2014). Information Needs of Urban Poultry Producers in Owerri North Local Government Area of Imo State, Nigeria. International Journal of Agricultural Innovations and Research. ISSN 2319-1473, Volume 2, Issue 6: pg 882-886

Aning, K. G., (2006). The Structure and Importance of Commercial and Village Based Poultry in Ghana: Final Review Report.

Busari, A. O., \& Okanlawon, I. N. (2015), Economic Appraisal of Small and Medium Scale Poultry Egg Production in Ife and Ilesha Metropolis, Osun State. Nigeria/Turkish Journal of Agriculture- Food Science and Technology 3(7). 5620565, 2015. ISSN: 2148-127X

Collence, T. C (2012).Knotting and Networking Agricultural Information Services through Web 2.0 to Create Informed Farming Community: A Case of Zimbabwe. World Library andss. Retrieved $5^{\text {th }}$ of November 2016 from http://conference.ifla.org/ifla 78

Henderson, A. \& Bowley, R. (2010). "Authentic Dialogue? The Role of "Friendship" in Social Media Recruitment Campaign”. Journal of Communication Management 14(3): 237-257.

Kietmann, H. J., \& Kristopher, H. (2011). Social Media? Get serious! Understanding the functional building blocks of social media. Business horizons 54:241-251

Kwado, A. O., \& Daniel, A. M. (2012). The Importance of ICTs in the Provision of Information for Improving Agricultural Productivity and Rural Income in Africa. United Nations Bureau for Africa.

Lagos State Business Directory (2012). Information Supplied by Minstry of Commerce and Industry. LSBD, Ikeja, Lagos State. www.lagostate.gov.ng

sMorrison, L. C. (2015). The Exploration of Social Media as a Media Relations Tool for Agricultural Organizations. M.Sc Thesis. The Ohio State University. Ohio. U.S.A.

Oladeji, J. O. (2011) Sources and utilization of poultry production information among poultry farmers in Oyo State. International Journal of Livestock Production, ISSN 2141-2448, vol. 2 (2) pp, 011-016.

Olaniyi, O. A. (2013). Assesment on Utilization of Information and Communication Technologies (ICTs) Among Poultry Farmers in Nigeria: An Emerging Challenge. Transitional Journal of Science and Technology June 2013 edition, ISSN 1857-8047. vol. 3, No 6:29-43.

Stanley, Sophie. (2013). Harnessing Social Media in Agriculture. A Report for the New Zealand Nuffield Farming Scholarship Trust. Accessed on January $10^{\text {th }}$, 2017 from http://www.nuffield.org.nz/uploads/media/S_Stanley_2013_Final_Report.pdf

Tweeten, J. F. (2014). Perceptions Regarding Importance and Frequency of Use of Selected Communication Tools by Iowa Cattle Producers. Retrieved from Digital Depository @ Iowa State University. 13749. 